\title{
7: $99916026-99921443$
}

National Cancer Institute

\section{Source}

National Cancer Institute. 7: 99916026-99921443. NCI Thesaurus. Code C42397.

Physical location of GNB2_Gene 